
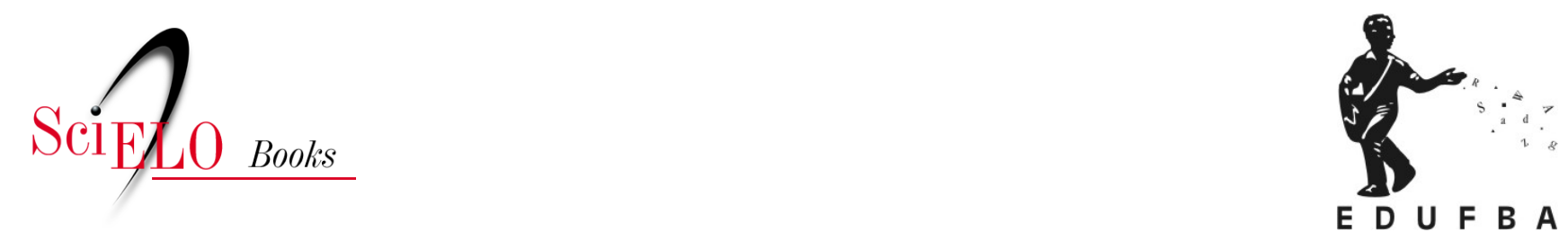

\title{
América Hispânica branqueia a raça - leis (não) escritas de branqueamento e mestiçagem
}

\author{
Tanya Katerí Hernández \\ Arivaldo Santos de Souza \\ Luciana Carvalho Fonseca \\ (Tradutores)
}

\section{SciELO Books / SciELO Livros / SciELO Libros}

HERNÁNDEZ, T.K. América Hispânica branqueia a raça - leis (não) escritas de branqueamento e mestiçagem. In: Subordinação racial no Brasil e na América Latina: o papel do Estado, o Direito Costumeiro e a Nova Resposta dos Direitos Civis [online]. Translated by Arivaldo Santos de Souza and Luciana Carvalho Fonseca. Salvador: EDUFBA, 2017, pp. 31-52. ISBN: 978-85-232-2015-0. https://doi.org/10.7476/9788523220150.0004. \section{International license.}

All the contents of this work, except where otherwise noted, is licensed under a Creative Commons Attribution 4.0

Todo o conteúdo deste trabalho, exceto quando houver ressalva, é publicado sob a licença Creative Commons Atribição $\underline{4.0}$. 


\section{América Hispânica branqueia a raça - leis (não) escritas de branqueamento e mestiçagem}

Os países da América Hispânica, pouco tempo depois de terem declarado a abolição de todas as formas de escravidão (principalmente entre os anos de 1850-1886), também se deparam com o crescimento da eugenia, um movimento pseudocientífico que buscava melhorar a raça humana preservando a pureza genética dos brancos. (GALTON, 1869) Assim, qualquer investigação do papel do direito do século XIX na regulação racial na América Latina deve considerar a influência da eugenia na região. Este capítulo avalia o papel da eugenia nas políticas estatais latino-americanas e as práticas costumeiras de exclusão racial delas resultantes. Para demonstrar os padrões regionais seguidos pelo direito costumeiro de regulação racial, este capítulo fornece uma visão geral das leis costumeiras latino-americanas de inspiração eugênica, ao passo que o capítulo 3 apresenta um estudo de caso minucioso do Brasil com o fim de detalhar o desenvolvimento do direito costumeiro de regulação racial no maior país da América Latina, o qual conta com a maior densidade de afrodescendentes.

Noções eugênicas europeias associaram a prevalência de não brancos na América Hispânica ao atraso de nações mestiças. (MARTíNEZ-ECHAZÁBAL, 1998, 
p. 23-24) Entre 1880 e 1930, intelectuais hispano-americanos encontraram suporte para seu próprio elitismo racial em teorias raciais europeias, como a da eugenia, que afirmava a inferioridade inata dos não brancos. (HELG, 1990, p. 37-38) Tendo em conta o maior número de pessoas de ascendência africana e indígena na América Hispânica, a região desenvolveu sua própria forma de eugenia a partir dos conceitos de branqueamento e mestiçagem. A mestiçagem corresponde à crença no uso da mistura racial para clarear a cor da pele da nação e torná-la mais branca, assim promovendo harmonia racial. Essa compreensão teórica ampla de mestiçagem, que é o foco deste capítulo, coexistiu com uma noção mais estrita de mestiçagem como mistura racial entre brancos e indígenas, que criou a identidade racial mestiça.

O branqueamento é um conceito de um significado individualizável, pessoal, e outro nacional, mais amplo. No nível individual, o branqueamento gira em torno do desejo de uma aparência branca e a ambição de ter filhos mais claros por meio de relações inter-raciais. Acredita-se que filhos de pele mais clara terão mais oportunidades de mobilidade social. Ao mesmo tempo, a valorização individual da branquitude é muito mais influenciada pela promoção nacional da branquitude, mais bem exemplificada pelas representações das relações inter-raciais como aquelas que "melhoram a raça". No nível nacional, o branqueamento é um conceito que descreve não só uma campanha concreta, de construção nacional e patrocinada pelo Estado para branquear a população, mas também a ideologia racial geral que valoriza a branquitude. Portanto, o branqueamento é um projeto mais amplo do que as oportunidades concedidas no período colonial ao seleto grupo de pessoas de ascendência africana na classe alta, as quais podiam alterar oficialmente sua identificação racial por meio de uma petição e do pagamento à Coroa Espanhola por um certificado de branquitude conhecido como cédula de gracias al sacar. (KING, 1951, p. 640-647) Isso porque o branqueamento, ao contrário desses certificados, buscava beneficiar toda a nação com uma imagem branca, e não apenas as pessoas de ascendência africana que buscavam ter os mesmos direitos e privilégios dos colonos brancos.

Apesar de distintas, todas as tentativas feitas para branquear a população ou a imagem da nação nos países da América Hispânica foram calcadas na crença eugênica de superioridade branca. A base "científica" da eugenia divergiu na América Hispânica se levarmos em consideração os enfoques europeu e estadunidense. Na Europa e nos Estados Unidos, o livro de Gregor Mendel 
de 1866, Princípios da Hereditariedade, foi usado para desenvolver uma teoria eugênica que postulava que pessoas bem-sucedidas tinham uma boa carga genética, ao passo que pessoas e grupos em desvantagem tinham uma má carga genética, sendo que nenhum nível de desenvolvimento social poderia remediar tal fato; logo a pureza dos bons genes deveria ser protegida a qualquer custo. (STEPAN, 1991, p. 27-28) Em contraste, a abordagem da América Hispânica para a eugenia foi culturalmente adaptada e favoreceu a conceituação que se assemelhava às primeiras ideias sobre hereditariedade de Jean Baptiste Pierre Lamarck. (BURKHARDT, 1977) A teoria de Lamarck considerava que forças externas influenciavam a hereditariedade de modo que as características que um indivíduo adquiriu ao se adaptar a um ambiente poderiam ser herdadas por gerações futuras. Ainda que mais tarde a teoria de aquisição genética de Lamarck tenha sido rechaçada, a mesma teve um grande apelo para os países da América Hispânica que buscavam amenizar presunções negativas, presunções europeias de que sua numerosa população de pessoas de ascendência africana e indígena tornava a nação inferior. Em vez de se ver condenado pelo predomínio das "raças inferiores" que a eugenia de Mendel considerava irremediável, o lamarckismo, mais flexível, considerava que com intervenção externa novas características poderiam ser adquiridas e, então, herdadas pelos descendentes. Consequentemente, muitos países da América Hispânica aprovaram leis higienistas para sanar e melhorar as classes inferiores. (STEPAN, 1991, p. 85-89) Ao mesmo tempo, legislação exigindo exames médicos pré-nupciais foi instituída para desmotivar a reprodução de classes inaptas, consideradas como mais propensas a doenças venéreas, alcoolismo, doenças mentais e doenças crônicas. (STEPAN, 1991, p. 122-128)

Além do mais, a noção de aquisição genética de Lamarck, intuitivamente, fornecia suporte indireto para o conceito de mestiçagem, segundo o qual as relações inter-raciais entre brancos e negros fariam com que a prole resultante adquirisse determinada branquitude e todos os atributos positivos socialmente associados a ela. (ALONSO, 2004, p. 462; TELLES, 2004, p. 28) A partir desse raciocínio, ao longo do tempo, o gene da branquitude presumivelmente "mais forte" predominaria na população e o número de pessoas negras diminuiria. Por essa razão, a noção eugênica de miscigenação racial construtiva da América Hispânica foi considerada uma contribuição original para um campo em que tradicionalmente a mistura racial era vista como algo degenerativo. (STEPAN, 1991, p. 170) Essa característica está bem refletida 
na citação do influente filósofo mexicano José Vasconcelos, que ressaltava os benefícios de uma nova raça mestiça, chamada por ele a "raça cósmica”, pela qual "os tipos inferiores da espécie serão absorvidos pelo tipo superior. Dessa maneira, por exemplo, o Negro poderia se redimir, e passo a passo, por extinção voluntária, os grupos mais feios darão caminho para os mais bonitos”. (VASCONCELOS, 1997, p. 30)

Em resumo, tendo como pano de fundo a pseudociência da eugenia lamarckiana, branqueamento e mestiçagem operaram juntos e independentemente para reforçar o processo de construção de uma nação no período posterior à emancipação com vistas a reduzir a negritude e diluí-la na nova raça criada. O branqueamento na abordagem do ideal de embranquecimento gradual de uma geração para a outra ofereceu meios para eliminar parte do estigma de atraso e para fazer oposição filosófica à eugenia europeia. Por sua vez, a mestiçagem rebatia o rótulo de nação impura valendo-se de uma bem construída ilusão de superioridade moral por ter resolvido problemas raciais por meio da minimização das diferenças raciais e da criação de uma democracia racial, cujas raças estariam mescladas. A maneira pela qual diferentes países da América Hispânica responderam à eugenia variou conforme o grau em que foram capazes de atrair imigrantes europeus e o tamanho de suas populações indígenas. Alguns países focaram somente no projeto de branqueamento (Argentina, Uruguai e Chile), outros voltaram mais atenção para a articulação de um orgulho acerca da mistura de raças que incluía a negritude (Colômbia, Cuba e Venezuela), ou uma "mestiçagem monocultural" que se fundava na mistura de indígenas com brancos com uma exclusão total de negros (Equador e México). (MUTEBA RAHIER, 2008, p. 148-182) Mesmo assim, como a discussão sobre as particularidades dos vários países irá mostrar, todas as estratégias foram essencialmente orientadas por um sentimento antinegro.

\section{Argentina como a síntese do branqueamento}

A imigração foi frequentemente a primeira área de atuação estatal para a promoção dos projetos de construção nacional baseados na mestiçagem e no branqueamento. De fato, debates sobre as políticas de imigração na América Hispânica foram quase sempre concebidos a partir da ideia de raça. (BLETZ, 2003, p. 9) A Argentina se destaca por ter focado exclusivamente na implementação do branqueamento ao intensificar a imigração de europeus. Depois da 
emancipação constitucional dos escravos em 1853, a imigração fez duplicar a população argentina entre 1869 e 1895, passando de 1,8 milhão para 4 milhões. Em 1914, a população havia dobrado novamente, fazendo com que $30 \%$ da população fosse nascida no estrangeiro. O enfoque argentino na imigração europeia em particular é demonstrado pelo fato de que somente entre 1880 e 1900 quase um milhão de europeus migraram para a Argentina. (REID ANDREWS, 1980, p. 20,178) Esse número só é superado pela taxa de imigração europeia para os Estados Unidos. (BLETZ, 2003, p. 79) A explosão imigratória para a Argentina não foi mera coincidência, mas o resultado de um esforço concreto do governo daquele país.

A Constituição original de 1853 incluiu um dispositivo voltado à promoção da imigração:

O governo federal deve fomentar a imigração europeia; e não deve restringir, limitar ou onerar com tributo de qualquer espécie a entrada no território argentino de estrangeiros que venham com o propósito de arar a terra, aperfeiçoar a indústria e introduzir e ensinar as artes e as ciências. (ARGENTINA, 1853, art. 25)

Além do mais, um provimento constitucional subsequente explicitamente declarava que:

Estrangeiros gozam no território nacional de todos direitos civis dos cidadãos; podem exercer indústria, comércio e profissão; possuir bens, comprar e vender bens imóveis; navegar nos rios e costas; praticar livremente sua religião; testar e casar conforme as leis. Não são obrigados a aceitar a cidadania, nem a pagar contribuições compulsórias extraordinárias. Podem obter nacionalidade depois de residir dois anos no país; mas, as autoridades podem reduzir o período de tempo para aqueles que assim o solicitarem, alegarem e provarem serviços prestados à República. (ARGENTINA, 1853, art. 20)

Depois disso, Domingo Sarmiento, presidente da Argentina de 1868 até 1874, demonstrou explicitamente o interesse do governo na imigração europeia com o propósito de embranquecer a população, e declarou que "corrigiria o sangue indígena com novas ideias que acabariam com o medievalismo” do país. (REID ANDREWS, 1980, p. 103) Com efeito, o branqueamento por meio da imigração buscava modernizar o país com o aumento da reserva genética 
"capaz" de realizar a modernização. O mandato constitucional pela imigração europeia se exteriorizou inclusive na alocação de subsídios públicos para atrair os imigrantes para a Argentina. (REID ANDREWS, 2004, p. 136)

Os imigrantes europeus foram bem recebidos no mercado de trabalho e, simultaneamente, os afro-argentinos foram excluídos do mesmo. Em 1914, os estrangeiros na Argentina dominavam quase todas as categorias de trabalhadores qualificados, a despeito de representarem apenas 30\% da população. (KLEIN, 1983, p. 323) Os italianos, que fizeram parte das primeiras grandes ondas imigratórias e, por conseguinte, predominavam sobre a população estrangeira na Argentina, representavam uma grande porcentagem dos proprietários de terra. O censo de 1914 indicou que 25\% dos italianos de 20 anos ou mais eram proprietários (um dado que se aproxima da média nacional). (KLEIN, 1983, p. 318321) Em Buenos Aires, conforme o censo de 1909, os imigrantes italianos possuíam $38 \%$ dos estabelecimentos comerciais na cidade, a despeito de representar somente $22 \%$ da população da cidade. (KLEIN, 1983, p. 321) Os números de Buenos Aires são particularmente relevantes se levarmos em consideração a densidade da população afro-argentina na cidade à época. (REID ANDREWS, 1980, p. 64-200) Em 1887, os italianos eram 32\% da população da cidade, representavam $53 \%$ da força de trabalho na indústria e eram 57,5\% dos proprietários de estabelecimentos industriais. Em contraste, os nascidos na Argentina, que perfaziam $47 \%$ da população da cidade, representavam apenas pouco mais de $20 \%$ dos proprietários e trabalhadores no comércio, $16 \%$ da força de trabalho na indústria e menos de $10 \%$ dos proprietários de estabelecimentos industriais. (BAILY, 1983, p. 284) Esses indicadores contundentes de quão bem os imigrantes italianos rapidamente se integraram à economia nacional argentina apoiam a hipótese de que a elite argentina considerava a imigração europeia de italianos como uma bem-vinda portadora da civilização. Com o influxo de imigrantes na população argentina e as relações inter-raciais entre esses e a população indígena, uma "população biologicamente superior" poderia ser criada. Simultaneamente, a população afrodescendente, "vadia, preguiçosa”, foi substituída no mercado de trabalho por imigrantes europeus. Muitas das categorias profissionais que afro-argentinos desempenhavam outrora foram dominadas por imigrantes europeus. A substituição da mão de obra negra por imigrantes europeus foi um fenômeno tão generalizado que alcançou até as forças armadas (uma área tradicionalmente aberta a homens afrodescendentes). (REID ANDREWS, 1980, p. 20-183) Atualmente, os afro-argentinos compõem aproximadamente $5 \%$ de 
toda população nacional (DOWNES, 2006) e estão tão marginalizados que Carlos Menem, presidente argentino de 1989 a 1999, uma vez declarou: "Não, nós não temos negros. O Brasil tem esse problema”. (GABINO, 2007)

\section{Apoio do Estado à imigração europeia em toda a América Hispânica}

Apesar de a Argentina poder ser considerada o exemplo mais bem acabado de substituição de pessoas de ascendência africana no mercado de trabalho por imigrantes europeus, esse exemplo está longe de ser uma aberração na América Hispânica e Caribe. Como resultado de vários esforços legislativos e do discurso público que fomentava a imigração europeia, o Brasil, Cuba e o Uruguai, juntamente com a Argentina, receberam mais de $90 \%$ dos 10 a 11 milhões de europeus que chegaram entre 1880 e 1930 às Américas. (REID ANDREWS, 2004, p. 129, 136) Antes disso, o Congresso da Grã-Colômbia (constituído pelos atuais Colômbia, Equador, Panamá e Venezuela, até sua dissolução em 1830) buscou incentivar a imigração europeia através da transferência de terras públicas. (SAFFORD, 1991, p. 2)

No Uruguai, que em 1880 tinha uma população de apenas 520 mil, o fluxo de imigrantes europeus entre 1880 e 1930 foi de 580 mil pessoas. (REID ANDREWS, 2010, p. 8) Em Montevidéu, o crescimento da população da cidade foi de 58 mil pessoas para 309 mil pessoas entre 1880 e 1908, o que pode ser diretamente atribuído ao afluxo de imigrantes europeus. Em verdade, em 1908 os moradores nascidos no exterior representavam $30 \%$ da população da cidade e sua proporção entre os trabalhadores da cidade era ainda maior. (REID ANDREWS, 2010, p. 40-42) Em 1925, publicações oficiais proclamavam o Uruguai como "totalmente de origem europeia", a despeito da existência de um expressivo número de jornais vibrantes e ativos publicados para a comunidade afro-uruguaia. (REID ANDREWS, 2010, p. 3-5)

De fato, tais periódicos negros são centrais para a documentação do papel do Estado uruguaio na produção da segregação racial no período posterior à abolição da escravidão. Jornais afro-uruguaios noticiavam sobre a frequência com que escolas públicas não admitiam crianças afrodescendentes e a exclusão racial em muitos cargos públicos, incluindo a polícia. (REID ANDREWS, 2010, p. 83-96) Claramente o Estado falhou em intervir para prevenir a exclusão racial de afro-uruguaios de instalações públicas, como hotéis, teatros, restaurantes, salões de dança e cafés. (REID ANDREWS, 2010, p. 105-109) Até 
que, em 1856, os afro-uruguaios passaram a reconhecer seu contexto racial como explicitamente segregado e puderam dizer que "segregação é o que nos preocupa e é o que nós queremos abolir.” (REID ANDREWS, 2010, p. 110) ${ }^{1}$

$\mathrm{Na}$ Venezuela, depois da emancipação dos escravos em 1854, o governo e os principais intelectuais expressaram abertamente o desejo por uma imigração europeia que permitisse efetuar uma "transfusão de sangue". (WRIGHT, 1979, p. 3) Os imigrantes preferidos eram da Irlanda, Alemanha, Ilhas Canárias e depois, da Itália. (ÁLVAREZ DE FLORES, 2006-2007, p. 90) Tentativas do governo para levar imigrantes europeus foram depois seguidas, em 1891, por uma legislação que proibia não brancos de entrarem no país. (PARÍS GARCÍA, 2002, p. 27) A política de imigração seletiva foi então incorporada na Constituição de 1906 com a proibição de imigração de qualquer afrodescendente. (WRIGHT, 1970, p. 22) O governo venezuelano foi também bastante claro em suas declarações oficiais sobre sua oposição à imigração negra, como exemplificado pela linguagem utilizada no seguinte comunicado do Ministério do Comércio: "A mera ideia de tal, ainda que sejam apenas rumores, já justifica nosso alarme. A introdução de indivíduos dessa raça, nas condições em que viriam, constitui uma verdadeira imigração, e não é essa classe de imigrantes de que a Venezuela precisa”. (WRIGHT, 1974, p. 325-347)

Por conseguinte, mesmo a chegada de marinheiros afro-estadunidenses foi considerada perigosa e os pedidos de desembarque da tripulação na costa venezuelana eram frequentemente negados. (WRIGHT, 1974, p. 337) A proibição legal da imigração não branca na Venezuela foi reafirmada com a lei de imigração de 1836, a qual instituiu a comissão de imigração para funcionar como intermediária entre os interesses mineiros, industriais e agrícolas venezuelanos e as autoridades emigratórias em vários países europeus. (WRIGHT, 1979, p. 8-9)

Como a Venezuela, a Costa Rica proibiu, em 1862, a imigração de pessoas de ascendência africana (e descendentes de chineses também) ao mesmo tempo em que promovia imigração de brancos com um decreto de 1896 autorizando o financiamento governamental anual de programas de incentivo à imigração europeia. (SOTO QUIRÓS, 2003, p. 2, 4) A Colômbia, o México e o Peru também aprovariam leis similares com o objetivo de estimular a imigração branca e impedir a imigração de negros, asiáticos e indígenas. (GONZÁLEZ

1 Citando Suárez Peña, presidente, em 1956, da organização afro-uruguaia Associación Cultural y Social Uruguay. 
NAVARRO, 1970, p. 145-69; VÁSQUEZ, 1970, p. 73-95; WADE, 1993, p. 11$12,15)$ Desse modo, as leis de imigração racialmente restritivas da América Latina tinham fins similares aos da lei de imigração estadunidense de 1924. Similarmente, a lei estadunidense restringiu a imigração com base em critérios de origem nacional e estabeleceu cotas que favoreciam a imigração de europeus procedentes do Ocidente e do norte. (ESTADOS UNIDOS, 1924)

A Colômbia, o Peru e a Venezuela efetivamente subsidiaram imigrantes europeus, com recursos para deslocamento e com benefícios fiscais. (MARTÍNEZ, 1998, p. 3; REID ANDREWS, 2004, p. 284) Os memorandos do governo da República Dominicana declaravam abertamente que os europeus eram os imigrantes desejados. (ELSON SIMMONS, 2009, p. 26) Como resultado, o governo celebrou contratos de trabalho com esses imigrantes e também lhes distribuiu terras. (HOETINK, 1970, p. 96-121) Além do mais, o governo dominicano orientou seus agentes diplomáticos na França, Holanda e Alemanha para fomentarem a imigração para Santo Domingo. No Equador, além de conceder vastas quantidades de terras e financiar o custo da viagem da Europa, o governo aprovou legislação permitindo que os assentamentos de europeus tivessem um significativo grau de autonomia em relação aos seus próprios municípios. (FOOTE, 2006, p. 265)

Da mesma forma, a Cuba do período posterior à independência buscou atrair imigrantes da Espanha e concedeu-lhes subsídios para incentivar a imigração, além de conceder terras e benefícios fiscais. (GOTT, 2005, p. 54) A campanha pela imigração europeia em Cuba foi energicamente conduzida pelos principais intelectuais cubanos, como José Antônio Saco, que queria que imigrantes da "raça branca" superior colonizassem Cuba. (GUEVARA, 2000, p. 50) Ensaístas cubanos da época clamavam que a imigração branca fosse promovida e que imigrantes não brancos fossem rigorosamente proibidos. De fato, um panfleto intitulado "La extinción del negro" projetava um futuro brilhante para Cuba, uma vez que "a raça negra irá desaparecer de nosso ambiente" com o aumento da imigração. (MUSTELIER, 1912) Quase um milhão de espanhóis foram para Cuba depois da independência, mais do que nos quatro séculos de regime colonial espanhol, representando 95\% do número total de pessoas que entraram no país até a década de 1920. (MASFERRER; MESA-LAGO, 1974, p. 348-384) Como resultado, dados censitários do período entre 1899 e 1943 refletem a participação dos negros nos setores mais baixos e mais mal pagos da economia, como na agricultura e nos serviços pessoais. (DE LA FUENTE, 
1995, p. 155) Durante essa época, os afro-cubanos foram sistematicamente excluídos da academia e dos processos eleitorais. (HELG, 1990, p. 53)

Quando os afro-cubanos descontentes com a situação tentaram formar seu próprio partido político em 1910, intitulado “el Partido Independiente de Color”, seus líderes foram presos e processados por conspirarem para implantar uma "Ditadura Negra”. (HELG, 1997, p. 63) Então, o senado cubano aprovou uma lei conhecida como Lei Morúa, que proibia a formação de partidos políticos a partir de critérios raciais. (AGUILAR, 1993, p. 21, 44) Quando o grupo negro organizou o partido político, desafiando a Lei Morúa, a repressão do governo, que ficou conhecida como a "Guerra das Raças de 1912”, foi violenta, expressiva e voltada para o objetivo nacional do branqueamento. (HELG, 1995, p. 193) Os afro-cubanos protestaram contra a medida e manifestaram frustração com seu baixo status econômico quebrando propriedades, incluindo engenhos de açúcar e lojas do comércio. Embora o protesto tenha se voltado para destruir propriedades e não machucar indivíduos, as forças armadas cubanas reagiram matando afro-cubanos e trabalhadores haitianos indiscriminadamente. (PÉREZ JUNIOR, 1986, p. 537) Um acadêmico afro-cubano recorda:

Eu ainda lembro como eu escutava, olhos bem abertos e enojados, as histórias, sempre sussurradas, sempre ditas como se estivessem revelando segredos indizíveis, sobre os horrores cometidos contra minha família e outros negros durante a guerra racial de 1912. [...] Tive um calafrio na espinha quando ouvi histórias sobre negros sendo caçados dia e noite, e sobre como homens negros eram pendurados pela genitália nos postes de iluminação das praças centrais das pequenas cidades de Cuba. (CASAL, 1979, p. 12)

Um observador direto também notou que o exército "estava decepando cabeças, sem qualquer razão, de todos os negros encontrados fora dos limites da cidade.” (PÉREZ JUNIOR, 1986, p. 537) Houve também um ataque por parte de voluntários civis brancos, que formaram milícias e ofereceram seus serviços "para defender o governo" contra os revoltosos políticos afro-cubanos. (HELG, 1995, p. 203) Desse modo, a guerra das raças de 1912 pode ser considerada um projeto nacional de branqueamento. Pelo menos um analista contemporâneo observou que o massacre foi uma tentativa de os brancos realizarem o sonho de um século: erradicar os negros da ilha de Cuba. (D’OU, 1916) Assim, uma década após a independência, os afro-cubanos estavam em piores 
condições econômicas e sua participação política, pela qual haviam lutado contra os espanhóis, não havia melhorado.

Mesmo os países que foram menos dependentes do trabalho escravo, como o Chile, empreenderam projetos nacionais de branqueamento. Apesar de o Chile ter abolido a escravidão em 1823, o governo abriu uma agência de imigração na Europa em 1882. A agência foi orientada a promover a oferta de concessões de terra para imigrantes europeus, como previsto em uma lei de 1824 que incentivava imigrantes europeus a estabeleceram oficinas em centros urbanos e comunidades em áreas esparsamente povoadas. (GOTT, 2007, p. 283, 286) Muitos dos imigrantes eram originários da Grã-Bretanha, da Suíça e dos estados alemães. Similarmente, o governo paraguaio buscou ativamente imigrantes europeus, os quais poderiam estabelecer suas próprias colônias. Por exemplo, em 1894, 600 indivíduos imigraram da Austrália para o Paraguai para fundar a colônia da "Nova Austrália”, e os alemães chegaram em 1886 para estabelecer a "Nova Alemanha”. (GOTT, 2007, p. 287) Do mesmo modo, no Uruguai, o Estado apoiou ativamente a imigração europeia. (REID ANDREWS, 2010) Uma fonte observa que a onda de imigração europeia se iniciou em 1830 e, em cem anos, mais de um milhão de europeus imigraram para o país. (RAMA, 1970, p. 28-50)

\section{Obstáculos regionais ao projeto de branqueamento pela imigração}

Em muitos países da América Hispânica, os efeitos demográficos do projeto de branqueamento pela imigração europeia foram mitigados por vários fatores. Imigrantes europeus não preferiam países da América Hispânica que eram menos desenvolvidos e mais pobres do que países maiores como Argentina e Brasil. A maior parte dos outros países na América Hispânica e Caribe não tinha recursos para atrair continuamente grandes ondas de imigrantes europeus por meio de subsídios públicos e concessões de terras. $\mathrm{O}$ envolvimento em guerras externas também dificultou a imigração europeia. O Peru, por exemplo, sofreu 10 invasões militares entre 1821 e 1895. (DE LA BARRA, 1959, p. 11-19) Durante o período de guerra, todos os estímulos prometidos aos imigrantes europeus foram obstados pelas limitações fiscais bélicas, as quais negavam privilégios e garantias para estrangeiros. (VÁSQUEZ, 2008, p. 79)

Ademais, em países como Costa Rica, Cuba, República Dominicana, Panamá e Venezuela, onde as indústrias estadunidenses dominavam o mercado e não 
acreditavam nas aspirações da América Hispânica de se tornar branca, quando se depararam com a necessidade de empregar mão de obra barata, optaram pelo recrutamento imediato e massivo da mão de obra das Índias Ocidentais que estava mais acessível. Assim, apesar da disposição legal proibindo imigração não branca para a Venezuela, o setor industrial recebeu entre seis mil e 11 mil trabalhadores sazonais negros das Antilhas anualmente. A resistência da América Hispânica à imigração de trabalhadores das Índias Ocidentais se manifestou na arena política e até em algumas legislações nacionais proibindo a imigração negra, como no caso do Panamá. A lei panamenha de 1926 também exigia que a proporção de trabalhadores nos empreendimentos no país fosse de, no mínimo, 75\% de indivíduos naturais do Panamá, em vez de residentes estrangeiros. (REID ANDREWS, 2004, p. 140) Em Cuba, o governo decretou em 1933 que 50\% de todos os empregados fossem naturais de Cuba e não residentes estrangeiros. (MASFERRER; MESA-LAGO, 1974, p. 362) Na Costa Rica, o empresário e minerador estadunidense, Cooper Keith, que foi contratado em 1871 para a construção de um sistema de linhas férreas, desafiou a disposição legal costa-riquenha proibindo a imigração negra com o propósito de contratar trabalhadores das Índias Ocidentais, os quais ele alegava serem "mais resistentes ao rigor dos trabalhos nos trópicos”. (HARPELLE, 1993, p. 104, 111) Mas devido ao desagrado costa-riquenho por imigrantes negros, o governo se recusou a reconhecê-los como cidadãos e a conceder-lhes direitos sobre as terras que eles cultivaram, uma vez assentados na Costa Rica. (HARPELLE, 1994, p. 98) De fato, aos imigrantes negros na Costa Rica não foram atribuídos os direitos da cidadania até 1949.

$\mathrm{Na}$ ausência de legislação voltada ao branqueamento, um líder nacional chegou a sancionar uma ordem militar para o extermínio direto dos residentes de ascendência africana. Foi o que ocorreu em 1937 sob a ditadura do dominicano Rafael Leónidas Trujillo, na sua campanha contra imigrantes haitianos. Após uma investigação internacional resultar em um acordo de reparação em 1938, Trujillo foi obrigado a pagar 525 mil dólares ao Haiti pelos assassinatos (esse valor corresponde a menos de 30 dólares por cada uma das 20 mil vítimas). (BELL, 2008, p. 41) Ao mesmo tempo em que Trujillo expulsava e exterminava imigrantes haitianos, ele também lançou um programa de colonização agrícola de larga escala para atrair imigrantes europeus. Como resultado, uma colônia judaica se estabeleceu em Sosúa durante a década de 1930.

O desejo hispano-americano por imigrantes europeus só diminuiu quando o influxo de europeus, em alguns países, começou a ser visto como um 
prenúncio das demandas dos movimentos trabalhistas. (BLETZ, 2003, p. 9194, 201) Assim, por exemplo, mesmo na Argentina, terra do projeto hispano-americano mais bem-sucedido de branqueamento, o Congresso em 1902 aprovou a Lei de Residência, autorizando a expulsão ou a negação de entrada de estrangeiros que ameaçassem a ordem pública. (BLETZ, 2003, p. 95-96, 201) Conforme essa lei, qualquer imigrante que participasse em sindicatos poderia ser deportado. Na mesma linha, a Argentina aprovou em 1910 a Lei de Defesa Social, que associou imigrantes com agitação no trabalho e identificou todos os terroristas como estrangeiros. Mas mesmo os imigrantes sendo marginalizados por ameaçarem os interesses econômicos das elites, aqueles assimilados foram integrados à imagem nacional dos argentinos, de uma maneira nunca acessível aos afro-argentinos. (BLETZ, 2003, p. 137-138) Assim, o branqueamento continuou a ser idealizado como o mecanismo para entender a hierarquia racial na Argentina e em toda a América Hispânica.

\section{A mestiçagem como complemento do branqueamento}

A Argentina, o Chile, o Uruguai e o sul do Brasil foram as poucas regiões que conseguiram usar o afluxo de imigrantes europeus para "embranquecer" a aparência das suas populações significativamente e diminuir a proporção de pessoas de visível ascendência africana. Em contraste, outras nações da América Hispânica com maiores proporções de negros e indígenas invocaram com mais veemência o discurso da mestiçagem para manter o privilégio branco. Mestiçagem literalmente se refere ao ato de miscigenação e à produção de uma identidade nacional mestiça, de uma raça mestiça, mas também engloba uma prática discursiva mais ampla de preferir uma hierarquia específica de raça, gênero e classe para a mistura racial. Para a mestiçagem, a noção de que a ancestralidade africana é inferior e necessita ser misturada com raças mais brancas para ser melhorada é central. Assim, com a mestiçagem, a branquitude continua sendo o ideal e o suposto lugar de poder e liderança, mesmo nas supostas "celebrações" nacionais de mistura racial. (SALCEDO-BASTARDO, 1983, p. 118)

O ideário supremacista branco subjacente à mestiçagem fica evidente quando consideramos as especificidades de raça e gênero no discurso de mistura racial. As mulheres brancas da elite foram completamente excluídas de tal idealização. Sua pureza racial e sua condição de classe não estão incluídas na mestiçagem. De fato, elas supostamente serviriam para dar continuidade à elite branca. 
Ao passo que as relações entre mulheres negras e homens brancos eram o foco da mestiçagem e de sua suposta capacidade de diminuir a presença negra no país. Enquanto a intimidade sexual inter-racial foi considerada uma prerrogativa de homens brancos, apenas imigrantes ou homens brancos da classe trabalhadora eram considerados como os maridos ideais das mulheres negras. (GUEVARA, 2005, p. 105-128, 109) O direito cubano do século XIX reflete essa abordagem da mestiçagem orientada pelo gênero ao proibir o casamento entre mulheres brancas e homens negros, enquanto permitia o casamento entre mulheres mestiças e homens brancos. (MILLER, 2004, p. 51) A mestiçagem serviu ao imperativo do branqueamento da América Hispânica do século XIX como a segunda melhor alternativa para promover socialmente aqueles que eram "brancos, mas não tão brancos assim”. (BHABHA, 1984, p. 132)

Assim, depois de tentativas fracassadas de embranquecer efetivamente a população, muitos países da América Hispânica usaram a mistura racial, considerada pelos europeus do século XIX como uma marca emblemática de uma sociedade atrasada, para reinterpretar a mestiçagem como um símbolo de orgulho nacional. (ISFAHANI-HAMMOND, 2004, p. 2) O capítulo 3 discute como o Brasil também empregou a mestiçagem a serviço da promoção de uma identidade nacional de inclusão que justificasse o privilégio racial branco. Os países da América Hispânica tinham uma fonte de referência imediata para a promoção da mestiçagem: as publicações de seus intelectuais famosos, incluindo o abolicionista cubano José Saco (GRAHAM, 1990, p. 39), o revolucionário independentista José Martí (SHNOOKAL; MUÑIZ, 1999, p. 161167), Simón Bolívar, na Venezuela (BIERCK JUNIOR, 1951, p. 110), e José Vasconcelos, no México. (VASCONCELOS, 1925) Enquanto Saco, Martí e Bolívar apresentavam a mestiçagem como uma fonte de unidade nacional frente às batalhas por independência contra a Espanha, Vasconcelos empregou a mestiçagem como uma defesa contra o discurso racial do imperialismo americano que retratava a América Latina como uma região inferior de não brancos. (MILLER, 2004, p. 43) Com a independência da Espanha (obtida entre 1810 e 1898), a mestiçagem também serviu aos governos caribenhos e hispano-americanos que buscavam um discurso inclusivo, com o qual pudessem consolidar o Estado-nação, enquanto mantinham uma hierarquia racial que impediria a integração dos recém-emancipados escravos africanos e seus descendentes, assim como dos muitos soldados negros recrutados para lutar em guerras de independência em nome do igualitarismo. (BLANCHARD, 2002, p. 499-523) Assim, 
por exemplo, em Cuba, José Antonio Saco, o mais eminente intelectual cubano do século XIX, antecipando o desafio que uma cidadania negra emancipada representaria para a supremacia branca, defendeu a imigração europeia e a miscigenação entre homens brancos e mulheres negras porque eles estabeleceriam o grande laço pelo qual a raça africana ascenderia para se misturar com a raça branca. (MARTÍNEZ-ECHAZÁBAL, 1998, p. 29; SACO, 1858, p. 208)

Na República Dominicana, a mestiçagem operou através do mito da vibrante ancestralidade indígena, com o propósito de não apenas afastar o país de uma identidade negra, mas também de diferenciá-lo de seu vizinho negro, o Haiti. Isso foi feito aumentando o papel dos ancestrais indígenas na República Dominicana para oferecer uma justificativa genética para a pele escura (apesar do fato de a grande maioria da população indígena ter sido morta nos 50 anos após a chegada de Colombo, em 1492). A publicação em 1882 do livro Enriquillo representou uma maior aproximação da identidade nacional com o passado indígena, supostamente mais importante que a influência genética da grande população africana. (DE JESÚS GALVÁN, 1882) A narrativa histórica descreve um líder indígena que chefia uma insurreição em 1519 contra os colonizadores espanhóis e negocia pacificamente um governo independente em troca de africanos fugidos. Como consequência da promoção do ancestral indígena dominicano, o termo "índio" se tornou o preferido para identificar uma pessoa mestiça, ainda que no século XIX poucas pessoas, se alguma, seriam capazes de encontrar uma ligação com um ancestral indígena verdadeiro. (FENNEMA; LOWENTHAL, 1987, p. 28) O termo "índio" é propositalmente ambíguo e corresponde ao que outros países hispano-americanos denominam "mulato", porém invoca um passado indígena inventado para elidir o significado dos ancestrais africanos desprezados. (HOWARD, 2001, p. 41) O índio se tornou um mito institucionalizado durante a ditadura de Trujillo (1931-1961), quando todos os documentos oficiais reificaram a mítica figura do índio. De fato, Trujillo ordenou que livros de história fossem reescritos para apagar o reconhecimento à ancestralidade africana dos dominicanos. (SIMMONS, 2009, p. 29)

Todavia, ao contrário da República Dominicana, alguns países na América Hispânica tinham e continuam a ter uma população indígena considerável. Nesses países, em que havia uma menor proporção de brancos e um maior número de pessoas indígenas de verdade, a mestiçagem também foi usada como resultado da mistura racial de brancos com aqueles que tinham ancestralidade 
indígena, assim dando origem ao mestiço, de forma a também extirpar o passado africano do imaginário nacional. O antropólogo Jean Muteba Rahier se refere ao fenômeno como um processo nacional de "mestiçagem monocultural”. (MUTEBA RAHIER, 2008, p. 148-182) Por exemplo, no México, a elevação do mestiço indígena que assimilou os valores culturais europeus à categoria de símbolo nacional foi feita paralelamente ao rebaixamento da negritude. (ROSENBLAT, 1954, p. 32-35) Como mencionado antes neste capítulo, o intelectual mexicano José Vasconcelos, figura-chave para a consolidação da mestiçagem, promoveu a ideia de uma "raça cósmica" miscigenada que permitiria a mestiços, com ancestralidade branca e indígena, a modernizar a nação, enquanto os "estoques inferiores" de negros sumiriam da população. Com a exclusão dos negros da conceitualização mexicana de mestiçagem, não é surpreendente o fato de que, no estudo de Bobby Vaughn sobre a identidade afro-mexicana contemporânea, ele "não encontrou, entre os negros, evidência da visão dominante no México de que a herança indígena é fundamental para sua própria herança”. (VAUGHN, 2005, p. 117-136, 123) Do mesmo modo, a mestiçagem operou para marginalizar a negritude e promover a assimilação dos indígenas em países como o Equador (WHITTEN JUNIOR, 1981, p. 45-94), a Guatemala (NÚÑEZ, 2006, p. 4-7) e Honduras (EURAQUE, 1998) (com o uso do termo ambíguo "ladino", para distinguir os não brancos, assimilados com o capital social, dos indígenas e negros excluídos do imaginário nacional).

Considerando que, assim como a mestiçagem, termos usados para designar aspectos raciais como "mulato" (em castelhano, mulatto) e "mestiço" (em castelhano, mestizo) são usados para identificar as pessoas percebidas como racialmente misturadas. Os termos em si podem ser vistos como ferramentas de branqueamento na medida em que o número de pessoas com ascendência africana é embranquecido com a elevação da categoria racial de "negro" para "mulato" ou "mestiço". (ROSA, 1996, p. 285) Assim, o aspecto branqueador da mestiçagem está particularmente evidente no emprego dos termos por parte dos governos em censos que, com frequência, omitem totalmente dados raciais.

\section{O censo como instrumento de branqueamento e mestiçagem}

As análises históricas feitas sobre os censos e outros dados demográficos na Argentina da primeira parte do século XIX sugerem de forma bastante 
persuasiva que os recenseadores reclassificaram grande parte da população afro-argentina que, em vez de ser incluída na categoria racial de "puro" negro ou moreno, em castelhano, era incluída nas categorias de "pardo" (pessoa mestiça também conhecida como mulatto) e "branco". (REID ANDREWS, 1980, p. 64-92) Devido à velocidade com que os números na categoria "moreno" diminuíram ao mesmo tempo em que os números da categoria "pardo" aumentaram - a uma velocidade muito maior que as possibilidades biológicas de geração de descendentes mestiços -, aparentemente, muitos morenos foram simplesmente reclassificados como pardos. À época, os recenseadores selecionavam a categoria racial do entrevistado baseados em uma inspeção visual em vez de o indivíduo se autoclassificar. (GOYER; DOMSCHKE, 1983, p. 41-49) A reclassificação estratégica de morenos para pardos, e de pardos para brancos, serviu para embranquecer a representação estatística da nação. Enquanto negros e pardos somados representavam, pelo menos, $25 \%$ da população nacional argentina em 1810, 1822 e 1838, em 1887, eles representavam apenas $1,8 \%$ da população. (DOWNES, 2006) Uma vez que a Argentina se comprometeu constitucionalmente a embranquecer o país por meio do afluxo de imigrantes europeus, os formulários do censo deixaram de usar a categoria racial ambígua de pardo, e todas as pessoas de ascendência africana passaram a ser agrupadas na categoria "de cor". O ano de 1887 foi a última vez em que o censo argentino incluiu a questão racial em um formulário até o censo de 2010. (DOWNES, 2006)

$\mathrm{Na}$ mesma linha, o vizinho Uruguai, em 1852, deixou de adotar a questão sobre categoria racial em seu censo, só tendo voltado a registrá-la a partir de 1996. (BUCHELI; CABELA, 2006, p. 2) Na Colômbia, o censo deixou de levantar informações sobre categoria racial em 1843, só tendo voltado a fazê-lo a partir de 1993. (BODNAR, 2005, p. 14) Na Costa Rica, desde o princípio do censo decenal em 1861, uma questão relacionada à raça foi incluída apenas nos censos dos anos de 1927, 1950 e, mais recentemente, no censo de 2000. (ALLEN, 2000; SCHKOLINK; DEL POPOLO, 2005) Uma mudança atual em direção à reinclusão da categoria "raça" nos censos em alguns países da América Hispânica é um resultado do lobby de organizações sociais do movimento social negro e de organizações internacionais que os apoiam. Com a classificação racial do censo, dados socioeconômicos podem ser desagregados para que se demonstre estatisticamente as disparidades raciais existentes. 
Apesar disso, as ações estratégicas de embranquecimento promovidas pelos recenseadores oficiais têm sido especialmente bem documentadas no caso de Porto Rico. Embora Porto Rico seja um território do governo estadunidense desde 1898, suas práticas culturais e política racial derivam mais diretamente do legado histórico e colonial espanhol de branqueamento e mestiçagem. (TORRES, 1998, p. 285-306) Por essa razão, suas práticas de embranquecimento a partir do censo explicam muito sobre a operação latino-americana de branqueamento e mestiçagem. A recente divulgação de estudos feitos com pequenas amostras dos censos de 1910 a 1920 tornou possível, pela primeira vez, documentar empiricamente o papel do censo no embranquecimento estatístico da população. A análise dos dados indica que um aumento dramático de 7,5\% na população branca entre 1910 e 1920 (um aumento maior que o dobro do aumento de qualquer outra década no século XX) não poderia ser atribuído somente ao aumento ligado a fatores naturais como fertilidade e migração. Pelo contrário, demógrafos têm demonstrado que o embranquecimento da população porto-riquenha foi quase inteiramente devido à reclassificação racial pelos recenseadores.

Assim, se a miscigenação tivesse sido a principal fonte de embranquecimento de Porto Rico nesse período, seria esperado que os resultados do censo de 1920 mostrassem um declínio na proporção da população classificada como negra, juntamente com um aumento na proporção da população classificada como mulata. Contudo, observa-se um declínio em ambos grupos da população, juntamente com um drástico aumento na proporção de brancos. (LOVEMAN; MUÑIZ, 2007, p. 915-939)

A partir de uma mudança cultural decorrente de como a branquitude era definida socialmente, os recenseadores em 1920 estavam 60\% mais propensos a classificar uma criança de pais de raças diferentes como branca que os recenseadores de 1910, apesar de a categoria racial mista, a de mulato, ainda constar como uma das categorias oficiais do censo. Após o censo de 1920, os seguintes continuaram a trajetória de embranquecimento até a classificação racial deixar de ser feita em 1952 (e ser retomada apenas no censo de 2000).

O controle estadunidense sobre Porto Rico depois da Guerra Hispano-Americana, de 1898, ironicamente possibilitou uma demonstração mais clara da operação hispano-americana e caribenha de branqueamento. Apesar de o Departamento de Recenseamento dos Estados Unidos organizar a contagem 
dos censos porto-riquenhos desde 1899, a preferência do governo estadunidense por precisão no que diz respeito às categorias raciais era subvertida pela implementação dos recenseadores porto-riquenhos. Como apenas a partir do censo de 2000 os porto-riquenhos passaram a se autodeclarar em termos de raça, o papel do recenseador na classificação racial da população porto-riquenha foi significativo. Historicamente, o Departamento de Recenseamento dos Estados Unidos encarregou um agente estadunidense para dirigir o recenseamento porto-riquenho, assim como para editar os resultados de modo a tornar o censo "racialmente preciso". Os agentes especiais foram selecionados entre as "melhores classes" porto-riquenhas para ajudar na edição dos resultados. (SKINNER, 1910) Em 1920, a maioria esmagadora (88\% dos 16.965 formulários) das reclassificações de indivíduos se deu da categoria "branco" para a categoria "mulato" (13.225) e um número muito menor para a categoria "negro" (1.665). (LOVEMAN; MUÑIZ, 2007, p. 923) Em resumo, a edição dos resultados controlada pelos Estados Unidos com uma abordagem mais restritiva em relação aos limites de branquitude enfatiza a maneira pela qual os formulários não editados refletem a operação de branqueamento porto-riquenha. Em outras palavras, os recenseadores porto-riquenhos reproduziram a ideologia de branqueamento e mestiçagem, a qual Porto Rico compartilhava com a América Hispânica, por meio da crescente classificação de porto-riquenhos mestiços de pele mais clara como brancos ao longo dos censos. De fato, o próprio Departamento de Recenseamento dos Estados Unidos admitiu o papel do branqueamento quando informou, em 1938, que o declínio da população porto-riquenha não branca "foi sem dúvida resultado da gradual mudança no conceito de classificação racial empregado pelos recenseadores” em Porto Rico. (ESTADOS UNIDOS, 1938, p. 17) Depois disso, ao ganhar maior autonomia política, o governo local de Porto Rico conseguiu, por meio de lobby, eliminar o campo sobre raça dos questionários do censo sob a justificativa de que a mistura racial porto-riquenha tornava aquela questão sem importância. Assim como o resto da América Hispânica, que relutou em aceitar as implicações da inferioridade racial afirmada pela eugenia do século XIX, Porto Rico recorreu ao branqueamento e mestiçagem como tropos da modernização e da unidade regional nos anos que sucederam a Guerra Hispano-Americana, com o subsequente controle do território pelos EUA e a atribuição, em 1917, da cidadania estadunidense para os porto-riquenhos na ilha. (TORRES, 1998, p. 285-306) Em 2000, o censo reincorporou a questão sobre raça e descobriu que $80,5 \%$ da população 
se autodeclarava branca, percentual superior à população autodeclarada branca nos Estados Unidos em 5,4\%, fato que fortemente sugere a continuidade da importância do ideal de branqueamento e mestiçagem. (GODREAU; LLORÉNS; VARGAS-RAMOS, 2010, p. 11-12) No censo de 2010, 75,1\% dos entrevistados porto-riquenhos selecionaram novamente apenas a categoria "branco", ao passo que apenas $3,2 \%$ selecionaram mais de uma categoria racial, 7,8\% selecionaram "alguma outra raça" e 12,3\% selecionaram "negro".

Embora o caso porto-riquenho certamente tenha sido extremo na sua articulação do branqueamento a partir do censo, outros países da América Hispânica e do Caribe também usaram o censo para dar suporte às suas ideologias raciais. Por exemplo, a opção generalizada de omitir informações raciais dos censos foi uma estratégia comum de promoção do branqueamento e, particularmente, da mestiçagem. Importante notar que mesmo enquanto muitos países hispano-americanos omitiram dos censos as questões sobre raça ou cor, esses países frequentemente incluíam questões sobre ascendência indígena, como foram os casos do Chile (MANDIVER, 1949, p. 138-146), México (AUGUSTINE-ADAMS, 1954, p. 331-342; GOYER; DOMSCHKE, 1983, p. 246), Panamá (AVILÉS BÓSQUEZ, 2000) e Venezuela. (MASON MANDIVER, 1949, p. 145) Assim, a eliminação de informações raciais dos formulários dos censos não pode ser vista simplesmente como uma crença nacional na não importância da cor, mas sim como uma recusa estratégica de reconhecer a presença de negros nos países da região. Isso é particularmente evidente no caso da Guatemala cujo censo de 1940 incluiu a categoria racial "negro". Porém, em 1950 o país omitiu essa categoria racial, mas manteve a categoria de indígena ou não indígena, negando, dessa forma, qualquer reconhecimento estatístico à população afro-guatemalteca. (AGUIRRE, 2000) De fato, um estudo histórico indica que a não identificação da população afro-guatemalteca começou na época colonial, quando um grande número de guatemaltecos de ascendência africana foi contabilizado como população mestiça de ancestralidade indígena ou branca. (LUTZ, 1994)

O México também é em um caso interessante de país em que, após a conquista da independência da Espanha em 1821, proibiu legalmente a classificação de pessoas por critério de raça em todos os documentos oficiais. A Assembleia Constituinte Soberana do México aprovou o Plano de Iguala que instituiu a probição. (GONZÁLEZ NAVARRO, 1970, p. 145-169) Todavia, a proibição legal não teve influência em vários órgãos governamentais 
que continuaram a diferenciar a população mexicana por critérios de raça (LOVELL BANKS, 2006, p. 199-234) e consideravam a população indígena mais inteligente que os descendentes de africanos. Como a condessa Paula Kolonitz, membro da elite política em 1864, declarou: "Os índios são muito mais inteligentes que os negros e seu caráter possui uma constituição mais nobre”. (CORREA, 2007, p. 80-95)

De fato, mesmo a contagem da população nacional imediatamente posterior à Revolução Mexicana (1910-1920), em 1921, continha classificações raciais: "indígena”, "indígena com branca” e "branca”. (AUGUSTINE-ADAMS, 2009, p. 124) Somente a categoria "negro com branco" foi omitida. A classificação racial era importante, mas a negritude foi considerada irrelevante para a identidade nacional do país. Apesar disso, os governos de alguns estados conduziram seus próprios recenseamentos que incluíam classificações raciais, tal qual Oaxaca em 1890, que incluiu as categorias "indígena”, "negro", "mestiço" e "branco". (CORREA, 2007, p. 95) No censo de 1890 do estado de Oaxaca, os afro-mexicanos com menos de 15 anos representavam 20\% da população. É muito improvável que toda essa população de $20 \%$ de jovens de Oaxaca tenha se extinguido antes do censo de 1920. Em outras palavras, os afro-mexicanos ainda estavam presentes, apesar da falta de disposição de incluí-los na contagem da população.

A interrupção da coleta de informações raciais nos formulários dos censos decenais na América Hispânica foi frequentemente acompanhada por um forte discurso governamental de mestiçagem. Por exemplo, quando o governo mexicano, em definitivo, omitiu oficialmente todas as classificações raciais no censo nacional de 1930 , a atitude foi tomada em meio a grande alarde (contudo, a contagem de indígenas era feita indiretamente por meio de questões sobre a língua falada, o que continuou nos censos entre 1940-1970). O Departamento Nacional de Estatísticas do México, em 1930, declarou que classificações raciais no censo não eram mais necessárias porque a população estava tão misturada racialmente e a estratificação social era uma questão de classe econômica, não de identidade racial. (AUGUSTINE-ADAMS, 2009, p. 125) A maneira pela qual o governo mexicano abertamente promoveu o censo como ferramenta de construção da nação também é particularmente digna de nota. Os cartazes disseminados pelo departamento de recenseamento como preparação para o censo de 1930 declaravam audaciosamente: "Responda ao censo, construa um país. Façamos as duas coisas juntas" e também "Responder ao censo fará um país”. (AUGUSTINE-ADAMS, 2009, 
p. 114) Com essas palavras, o departamento de recenseamento mexicano ironicamente representou a aspiração da América Hispânica de criar uma nação moderna por meio do recenseamento que refletiria uma cidadania nacional idealizada e distante da negritude.

Em suma, depois da emancipação dos escravos, a América Hispânica enquanto região buscou embranquecer sua população como veículo de modernização. Alguns países, como a Argentina, fizeram uso exitoso das leis de imigração e subsídios governamentais para embranquecer a população com o influxo de imigração europeia. Outros países da América Hispânica, menos bem-sucedidos em embranquecer suas populações por meio da imigração europeia, valeram-se da apresentação estratégica de censos oficiais para ocultar a presença demográfica de populações de ascendência africana. Esses esforços foram acompanhados de diversas tentativas de promoção da mestiçagem. Com efeito, as leis formais de imigração e as leis não escritas refletidas nas práticas de contagem dos censos e nas campanhas nacionais de identidade mestiça pretenderam marginalizar e limitar a cidadania plena dos afrodescendentes. Assim como as leis Jim Crow de segregação nos Estados Unidos, o branqueamento espanhol e as campanhas de mestiçagem, de modo semelhante, "mantiveram os negros em seus lugares" na ausência da escravidão. (SMITH, 1966, p. 379-387, 380)

A história da América Hispânica, baseada no uso racializado do direito legislado no contexto da imigração, desmente a narrativa de inocência racial que durante tanto tempo tem obstruído os esforços contemporâneos de igualdade racial. Similarmente, o envolvimento do Estado na política de recenseamento voltada ao branqueamento pode ser considerado um direito costumeiro de regulação racial. Na medida em que o Estado tinha uma prática costumeira de empregar o censo para embranquecer a população e, com isso, marginalizar a cidadania dos afrodescendentes, as políticas de Estado consolidaram o direito costumeiro de regulação racial. Não obstante, o Brasil se destaca por ser o país onde o desenvolvimento de um direito costumeiro de regulação racial foi mais amplo e mais documentado que no restante da América Latina. Por essa razão, o direito costumeiro de regulação racial brasileiro merece um exame mais detalhado no próximo capítulo. 